Article

\title{
Suppression of Cell Growth, Migration and Drug Resistance by Ethanolic Extract of Antrodia cinnamomea in Human Lung Cancer A549 Cells and C57BL/6J Allograft Tumor Model
}

\author{
Chi-Han Wu ${ }^{1}$, Fon-Chang Liu ${ }^{1}$, Chun-Hsu Pan ${ }^{2}{ }^{\mathbb{D}}$, Ming-Tsung Lai ${ }^{3}$, Shou-Jen Lan ${ }^{4}$, \\ Chieh-Hsi $\mathrm{Wu}^{2}$ and Ming-Jyh Sheu ${ }^{1, *}$ \\ 1 School of Pharmacy, China Medical University, Taichung 40402, Taiwan; \\ u101055003@cmu.edu.tw (C.-H.W.); fonchang008@gmail.com (F.-C.L.) \\ 2 School of Pharmacy, Taipei Medical University, Taipei 11031, Taiwan; \\ panch@tmu.edu.tw (C.-H.P.); chhswu@tmu.edu.tw (C.-H.W.) \\ 3 Department of Pathology, Taichung Hospital, Ministry of Health and Welfare Taiwan, \\ Taichung 40343, Taiwan; mtlailuke@gmail.com \\ 4 Department of Healthcare Administration, Asia University, Taichung 41354, Taiwan; sjlan@asia.edu.tw \\ * Correspondence: soybean13mtdtw@gmail.com.tw; \\ Tel.: +011-886-4-2205-3366 (ext. 5158); Fax: +011-886-4-2207-8083
}

Received: 11 January 2018; Accepted: 6 March 2018; Published: 9 March 2018

\begin{abstract}
The purpose of this study was to investigate the inhibitory activities of ethanolic extracts from Antrodia cinnamomea (EEAC) on lung cancer. Cell proliferation and cell cycle distribution were analyzed using (3-(4,5-Dimethylthiazol-2-yl)-2,5-diphenyltetrazolium bromide) (MTT) assay and flow cytometry, respectively. Wound-healing assay, Western blotting, and a murine tumor model were separately used to examine cell migration, protein expression, and tumor repression. Our results showed that EEAC induced cell cycle arrest at the G0/G1 phase resulting decreased cell viability in A549 cells. Moreover, EEAC up-regulated the growth-suppressing proteins, adenosine $5^{\prime}$-monophosphate-activated protein kinase (AMPK), p21 and p27, but down-regulated the growth-promoting proteins, protein kinase B (Akt), mammalian tarfet of rapamycin (mTOR), extracellular signal-regulating kinase 1/2 (ERK1/2), retinoblastoma protein (Rb), cyclin E, and cyclin D1. EEAC also inhibited A549 cell migration and reduced expression of gelatinases. In addition, our data showed that tumor growth was suppressed after treatment with EEAC in a murine allograft tumor model. Some bioactive compounds from EEAC, such as cordycepin and zhankuic acid A, were demonstrated to reduce the protein expressions of matrix metalloproteinase (MMP)-9 and cyclin D1 in A549 cells. Furthermore, EEAC enhanced chemosensitivity of A549 to paclitaxel by reducing the protein levels of caveolin-1. Our data suggests that EEAC has the potential to be an adjuvant medicine for the treatment of lung cancer.
\end{abstract}

Keywords: Antrodia cinnamomea; anti-migration; anti-proliferation; paclitaxel resistance; lung cancer

\section{Introduction}

In general, the five-year survival rate of the patients with lung cancer is only $15 \%$ [1]. Non-small cell lung cancer (NSCLC), a major histological type of lung cancer, shows lower susceptibility to traditional chemotherapy and radiation treatments. Therefore, a more effective agent should be investigated. 
For treatment of tumor metastasis, cell cycle arrest and migration inhibition are the targets of drug development. Several molecules are involved in the regulation of cell cycle and cell growth, including cyclin-dependent kinase (CDKs) and CDK inhibitors (CDKi) [2,3]. Additionally, AMP-activated protein kinase (AMPK), a cellular energy sensor, is involved in the control of tumor growth via activating p53-/p21 cascade and inhibiting the mTOR-mediated pathway [4]. Besides, Akt protein, known as an upstream regulator of mTOR, has been shown to stimulate cell growth and migration as well as to provide anti-apoptotic activity for cancer survival [5].

Moreover, matrix metalloproteinases (MMPs), are highly expressed in various types of human cancers and play a critical pathological role in tumor growth, metastasis and angiogenesis [6]. The extracellular signal-regulated kinase (ERK) associated with regulation of MMP-2 and MMP-9 proteins has been reported [7]. Furthermore, chemotherapy resistance is also associated with clinical unresponsiveness in cancer patients who receive chemotherapy drugs. Ho et al. showed that up-regulation of caveolin-1 was correlated with drug-resistant and poor progression-free survival rates in NSCLC patients [8]. Silencing of cav-1 has been evidenced to enhance doxorubicin-induced apoptosis and reduced lung metastasis in human renal cell carcinomas [9].

Antrodia cinnamomea (A. cinnamonea) is a medicinal fungus that only grows inside the rotten trunk of Cinnamomum kanehirae, a native tree species of Taiwan [10]. A. cinnamomea has been explored to evaluate its effect in different cancers or use of adjuvant medicine for chemotherapy [11,12]. Our previous studies identified two main constituents, zhankuic acid A and cordycepin, in ethanolic extracts of A. cinnamomea (EEAC) by HPLC/Mass-fingerprint analysis [13]. The present study attempted to evaluate the mechanisms of anti-cancer activities and synergistic effects of the EEAC in A549 human lung adenocarcinoma epithelial cells and a C57BL/6J allograft tumor model.

\section{Results}

\subsection{EEAC Induced Cell-Cycle Arrest and Reduced Cell Viability of A549 Cells}

Our results showed that various doses $(12.5,25,50,100$, and $200 \mu \mathrm{g} / \mathrm{mL})$ of EEAC reduced serum-stimulated cell growth of A549 cells in a dose-dependent manner (Figure 1a), and $\mathrm{IC}_{50}$ value of EEAC on A549 cells after a $24 \mathrm{~h}$ treatment was approximately $170 \mu \mathrm{g} / \mathrm{mL}$. Moreover, the results obtained from flow cytometry demonstrated that growth inhibition of EEAC may be partially mediated by cell-cycle arrest at G0/G1 phase (Figure 1b). Specifically, the proportion of cells in the G0/G1 phase increased from $56 \%$ (control group) to $66 \%(25 \mu \mathrm{g} / \mathrm{mL}), 68 \%(50 \mu \mathrm{g} / \mathrm{mL})$, and $71 \%(100 \mu \mathrm{g} / \mathrm{mL})$.

\subsection{Regulation of EEAC on Cell Growth-Associated Proteins in A549 Cells}

Several critical molecules involved in the regulation of cell growth were examined to understand the growth-inhibitory mechanisms of EEAC on A549 cells. Experimental data indicated that EEAC significantly increased the phosphorylation level of a growth-suppression protein, AMPK $\alpha$, as well as dose-dependently inhibited activations of several growth-promoting proteins, such as Akt, mTOR, $\mathrm{ERK} 1 / 2$ and $\mathrm{Rb}$. However, EEAC did not influence the total protein levels of these proteins (Figure 2a and Table 1). Furthermore, the cell cycle regulatory proteins, such as p27, p21, cyclin E, and cyclin D1, were also examined in A549 cells treated with EEAC for $24 \mathrm{~h}$. The protein levels of cyclin E and cyclin D1 were reduced, while the p21 and p27 protein levels were increased in A549 cells with EEAC treatment (Figure 2b). 
Table 1. Fold changes of detected proteins in A549 cells treated with EEAC.

\begin{tabular}{ccccc}
\hline \multirow{2}{*}{ Protein Name } & \multicolumn{4}{c}{ EEAC $(\boldsymbol{\mu g} / \mathrm{mL})$} \\
\cline { 2 - 5 } & $\mathbf{0}$ & $\mathbf{2 5}$ & $\mathbf{5 0}$ & $\mathbf{1 0 0}$ \\
\hline p-mTOR & 1 & $0.78 \pm 0.36$ & $0.85 \pm 0.37$ & $0.43 \pm 0.10^{* *}$ \\
p-Rb & 1 & $0.87 \pm 0.17$ & $0.86 \pm 0.01^{*}$ & $0.39 \pm 0.06^{* *}$ \\
p-AMPK & 1 & $2.42 \pm 0.02^{* *}$ & $2.49 \pm 0.11^{* *}$ & $2.49 \pm 0.51^{*}$ \\
AMPK & 1 & $1.89 \pm 0.28$ & $1.57 \pm 0.35$ & $1.51 \pm 0.46$ \\
p-Akt & 1 & $1.04 \pm 0.23$ & $1.00 \pm 0.17$ & $0.74 \pm 0.06^{*}$ \\
Akt & 1 & $1.59 \pm 0.27$ & $1.72 \pm 0.40$ & $1.98 \pm 0.72$ \\
p-ERK1/2 & 1 & $1.07 \pm 0.23$ & $0.80 \pm 0.10$ & $0.50 \pm 0.11^{*}$ \\
ERK1/2 & 1 & $1.13 \pm 0.02$ & $0.93 \pm 0.17$ & $0.89 \pm 0.05$ \\
\hline
\end{tabular}

${ }^{*} p<0.05$ and ${ }^{* *} p<0.01$ compared to the control group (treated with vehicle alone), respectively. p-mTOR: Phosphomammalian target of rapamycin; $\mathrm{p}$-Rb: Phospho-retinoblastoma protein; $\mathrm{p}$-AMPK: Phospho-AMP-activated protein kinase; AMPK: Adenosine 5'-monophosphate (AMP)-activated protein kinase; p-Akt: Phospho-protein kinase B; Akt: Protein kinase B; p-ERK1/2: Phospho-extracellular signal-regulating kinase 1/2; ERK1/2: Extracellular signal-regulating kinase $1 / 2$.

(a)

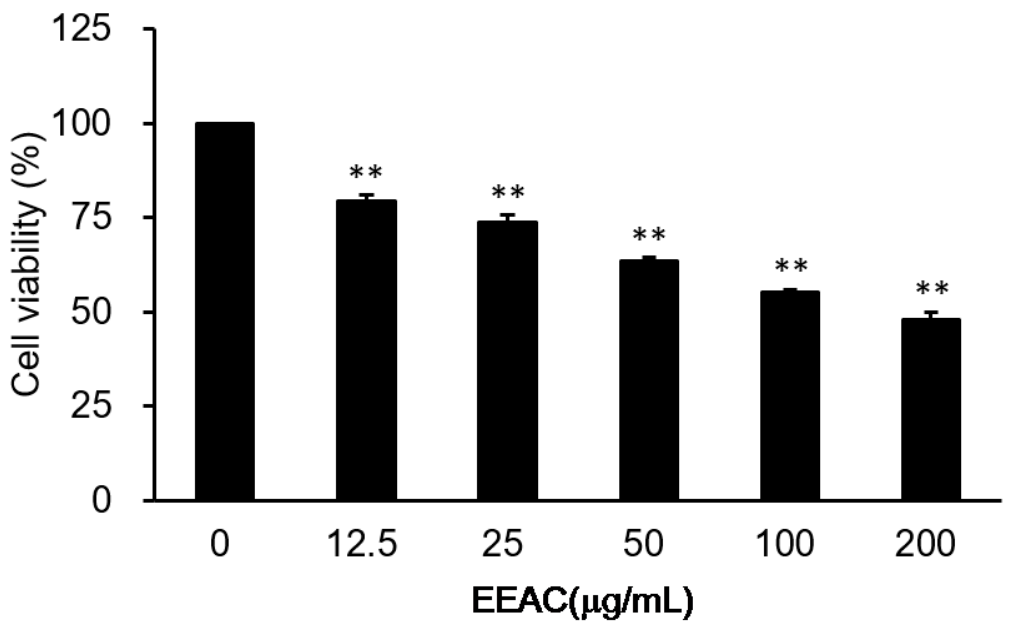

(b)

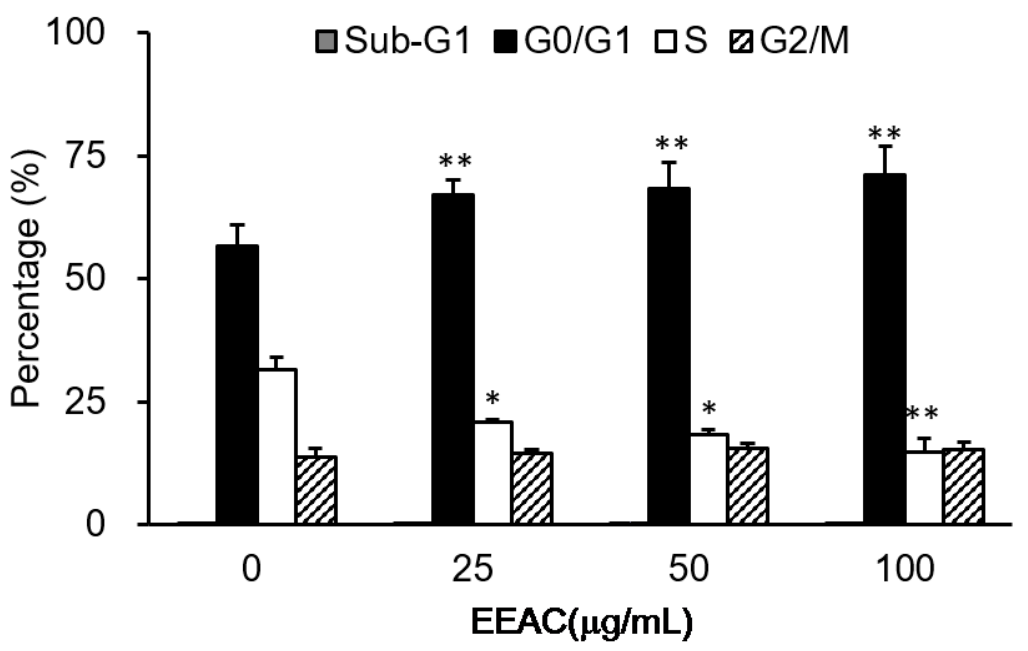

Figure 1. Growth regulation of ethanolic extracts from Antrodia cinnamomea (EEAC) in A549 cells. Cell viability and cell cycle distribution were, respectively, measured using an (3-(4,5-Dimethylthiazol2-yl)-2,5-diphenyltetrazolium bromide) (MTT) assay (a) and a flow cytometer (b) in A549 cells treated with various concentrations of EEAC for 24 h. $^{*} p<0.05$ and ${ }^{* *} p<0.01$ compared to the control group (without EEAC treatment), respectively. 
(a)

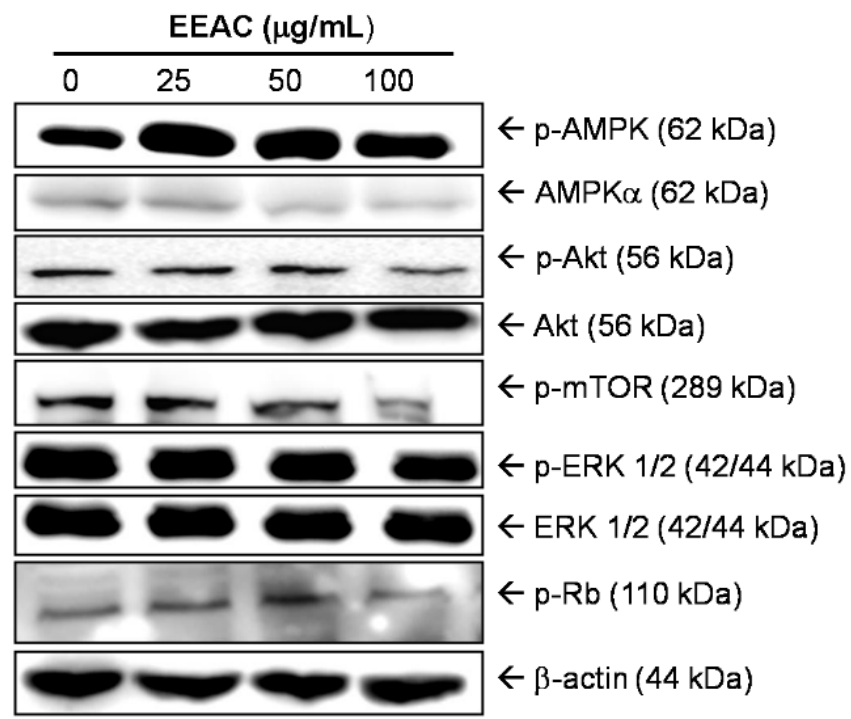

(b)
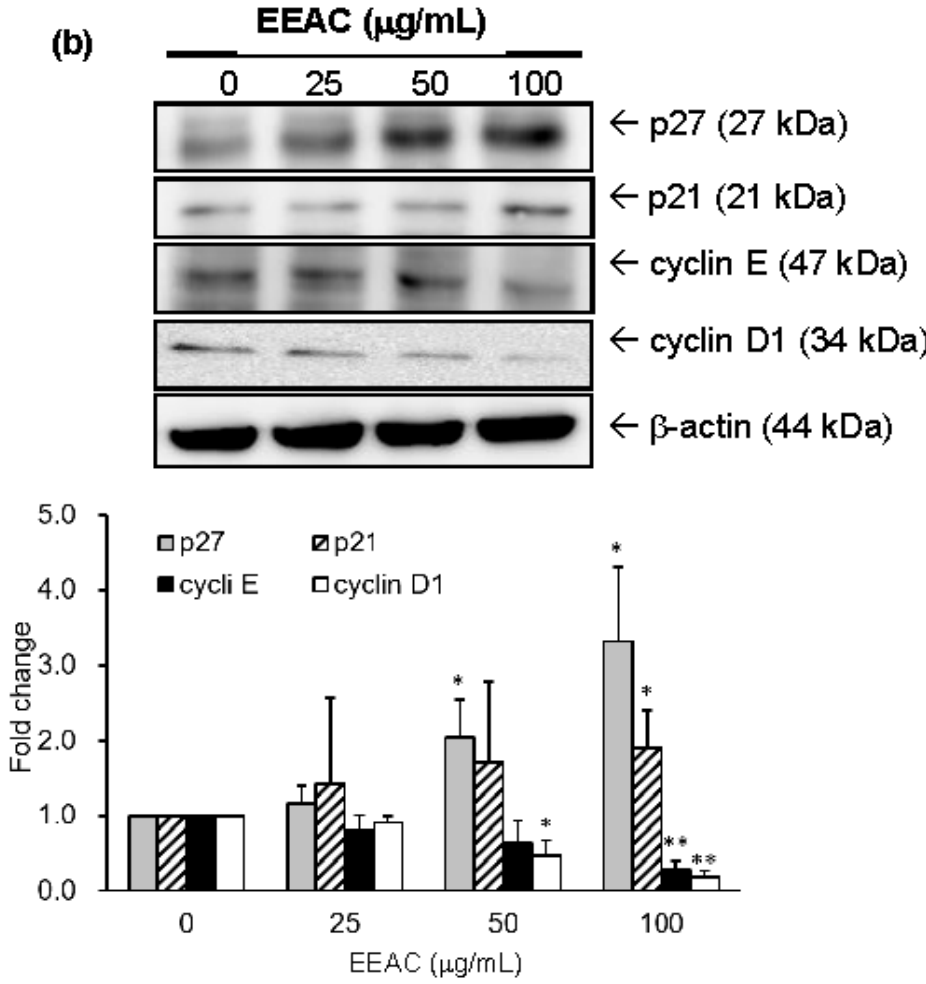

Figure 2. Effect of EEAC on cell growth-associated proteins in A549 cells. Cells were treated with several concentrations of EEAC for $30 \mathrm{~min}$ to examine the expression and/or activation levels of $\mathrm{AMPK} \alpha, \mathrm{Akt}, \mathrm{mTOR}$, and ERK1/2 (a). Each value represents the average of three independent experiments in Table 1. Protein expressions of p21, p27, cyclin D1 and cyclin E were incubated with the indicated concentrations of EEAC for $24 \mathrm{~h} \mathrm{(b)}$, and fold changes of individual proteins were shown as a histogram. ${ }^{*} p<0.05$ and ${ }^{* *} p<0.01$ compared to the control group (treated with vehicle alone), respectively.

\subsection{EEAC Suppressed Cell Migration of A549 Cells and Gelatinase Expression}

Our results showed that serum stimulated cell migration of A549 cells, and this stimulation can be markedly reduced by EEAC $(25,50$, and $100 \mu \mathrm{g} / \mathrm{mL})$ incubation in a dose- and time-dependent manner (Figure 3). Additionally, the protein levels of gelatinases (MMP-2) were down-regulated from $100 \%$ 
(control group) to 87\% $(25 \mu \mathrm{g} / \mathrm{mL}), 60 \%(50 \mu \mathrm{g} / \mathrm{mL})$, and 60\% (100 $\mu \mathrm{g} / \mathrm{mL})$ in A549 cells after $24 \mathrm{~h}$ treatment of EEAC (Figure 4). Moreover, MMP-9 were downregulated from $100 \%$ to $47 \%(25 \mu \mathrm{g} / \mathrm{mL})$, $48 \%(50 \mu \mathrm{g} / \mathrm{mL})$, and 32\% $(100 \mu \mathrm{g} / \mathrm{mL})$ in A549 cells after $24 \mathrm{~h}$ treatment of EEAC (Figure 4).

(a)

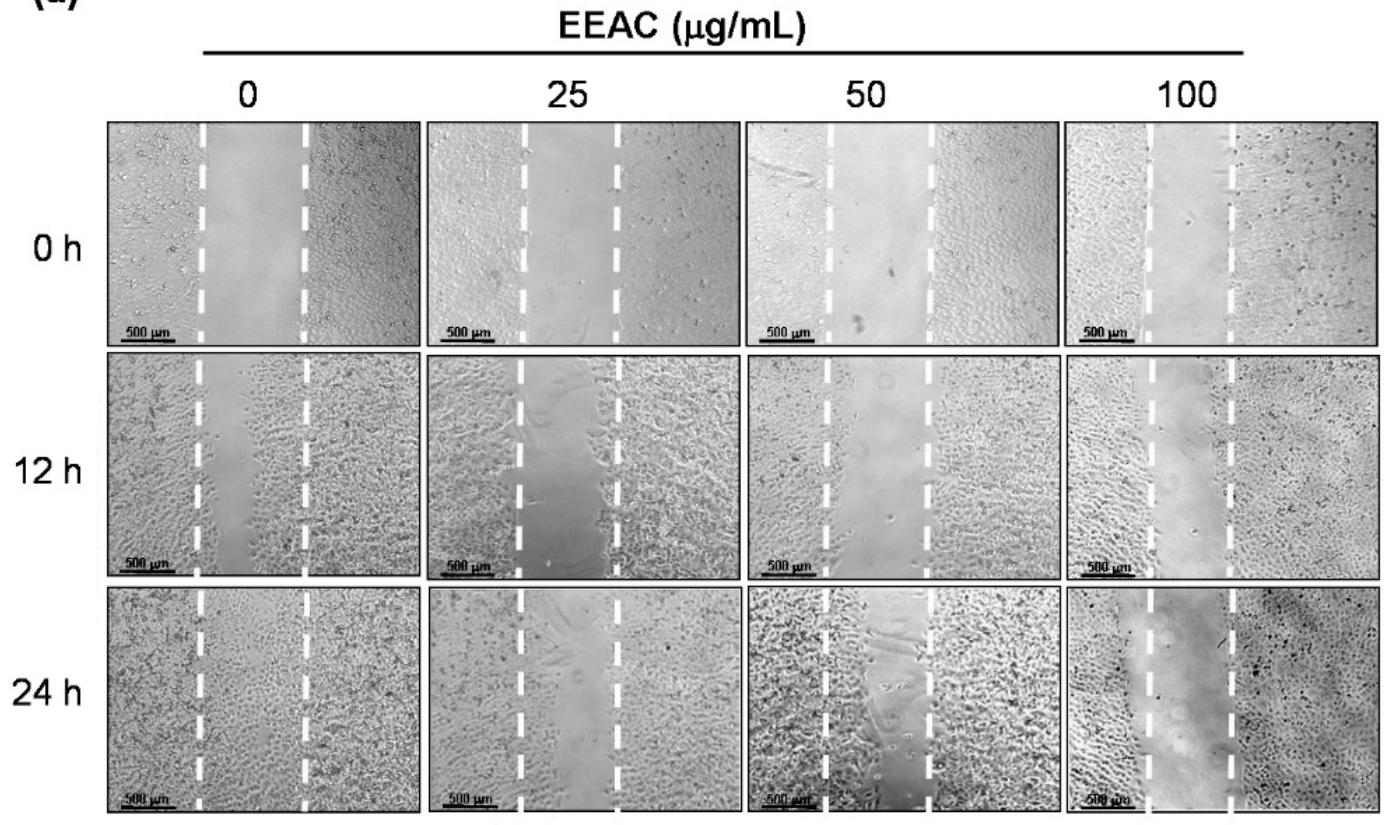

(b)

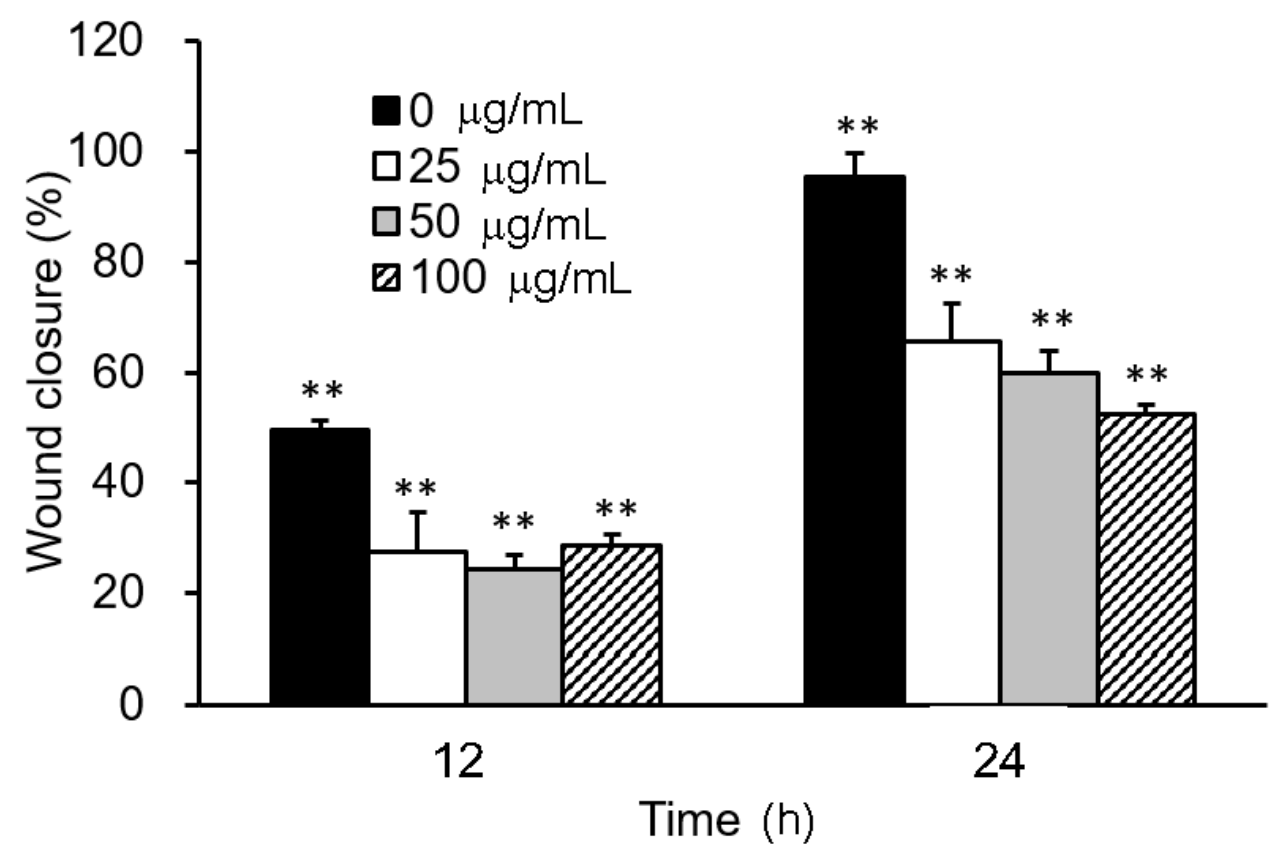

Figure 3. Inhibition of cell migration by EEAC in A549 cells. Cells were stimulated with 10\% FBS to induce cell migration and co-incubated with various concentrations of EEAC. The pictures were acquired after 0,12 and $24 \mathrm{~h}$ treatment of EEAC (a). Migration inhibition was presented as the percentage of wound closure by calculating the cell-free gap of each group compared to those at initial time (b). ${ }^{* *} p<0.01$ compared to those of individual group at initial time. 

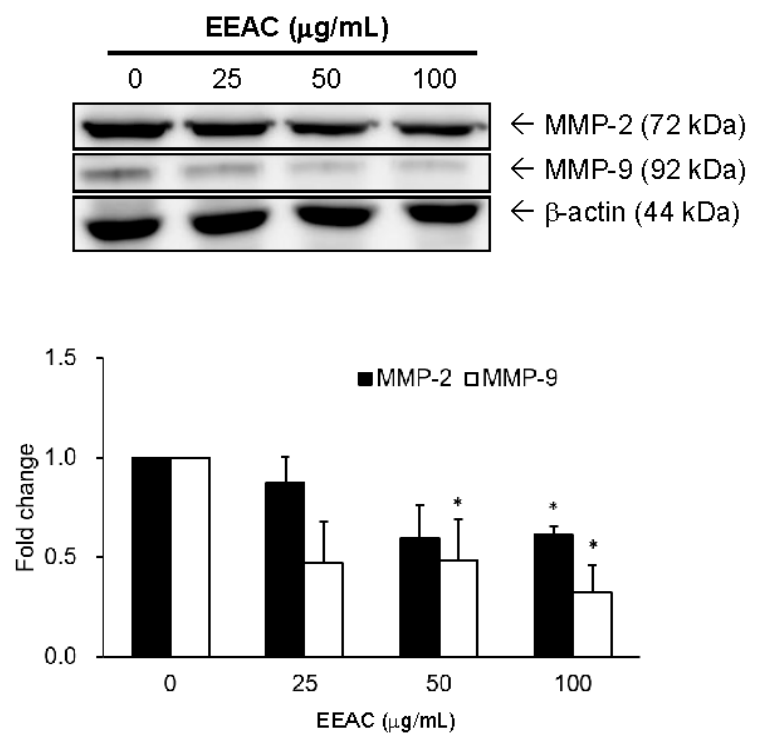

Figure 4. Suppression effect of EEAC on gelatinases in A549 cells. The expression levels of gelatinases, MMP-2 and MMP-9, were examined in A549 cells incubated with various concentrations of EEAC for $24 \mathrm{~h}$. The band intensities of each group were quantified and normalized to the control group, and the relative expressions of gelatinases were presented as fold change in a histogram. ${ }^{*} p<0.05$ compared to the control group (treated with vehicle alone).

\subsection{Zhankuic Acid A and Cordycepin Decreased Cyclin D1 and MMP-9 Expressions in A549 Cells}

Our investigation showed that expression levels of cyclin D1 and MMP-9 were markedly reduced in A549 cells after $24 \mathrm{~h}$ treatment with the bioactive compounds, zhankuic acid A $(7.2 \mu \mathrm{M})$ and cordycepin $(9.1 \mu \mathrm{M})$, identified in EEAC (Figure 5).
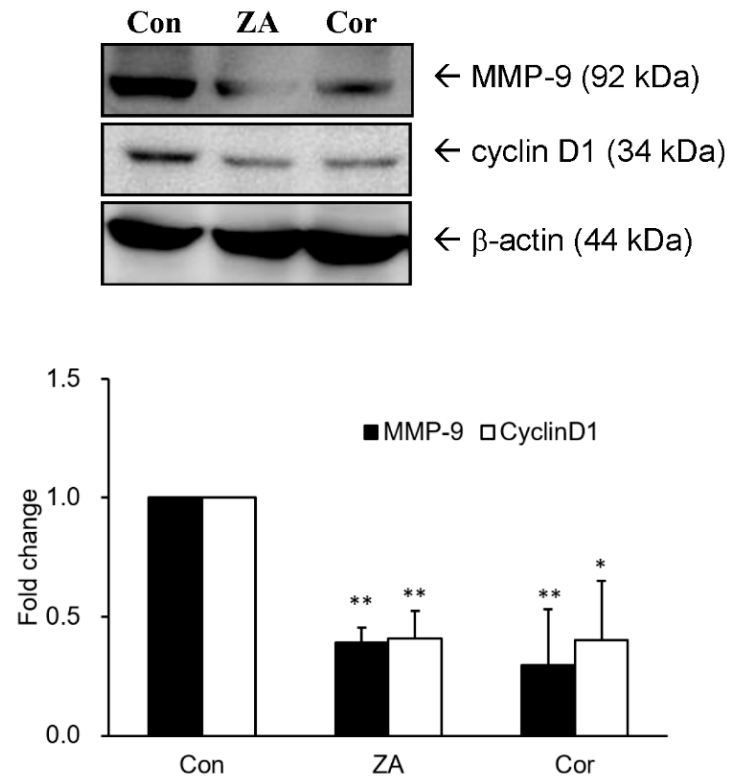

Figure 5. Effects of zhankuic acid A and cordycepin on the protein expressions of cyclin D1 and MMP-9 in A549 cells. The expression levels of cyclin D1 and MMP-9 were examined in A549 cells incubated with zhankuic acid A or cordycepin for $24 \mathrm{~h}$. The band intensities of each group were quantified and normalized to the control group, and the relative expressions of gelatinases were presented as fold change in a histogram. ${ }^{*} p<0.05$ and ${ }^{* *} p<0.01$ compared to the control group (treated with vehicle alone), respectively. Con, control; ZA, zhankuic acid A; Cor, cordycepin. 


\subsection{Regulation of EEAC on Chemosensitivity of A549 Cells to Paclitaxel}

Chemotherapy sensitivity of A549 cells to paclitaxel (Pac) was evaluated by using cell viability assays. Cells were treated with EEAC $(6.25 \mu \mathrm{g} / \mathrm{mL})$, Pac $(0.156 \mu \mathrm{M})$ or a combination of EEAC and Pac. In order to evaluate the synergic inhibitory effect of EEAC and Pac on cell growth of A549 cells, both concentrations of EEAC and Pac used in this experiment were the $\mathrm{IC}_{10}$ value. Data showed that the combination group exhibited an enhanced chemotherapy effect by decreasing cell viability by $15 \%$ as compared to the group treated with Pac alone (Figure 6a). Moreover, the combination group had significantly decreased protein expression levels of caveolin-1 (Cav-1) as compared to the paclitaxel group (Figure 6b).

(a)
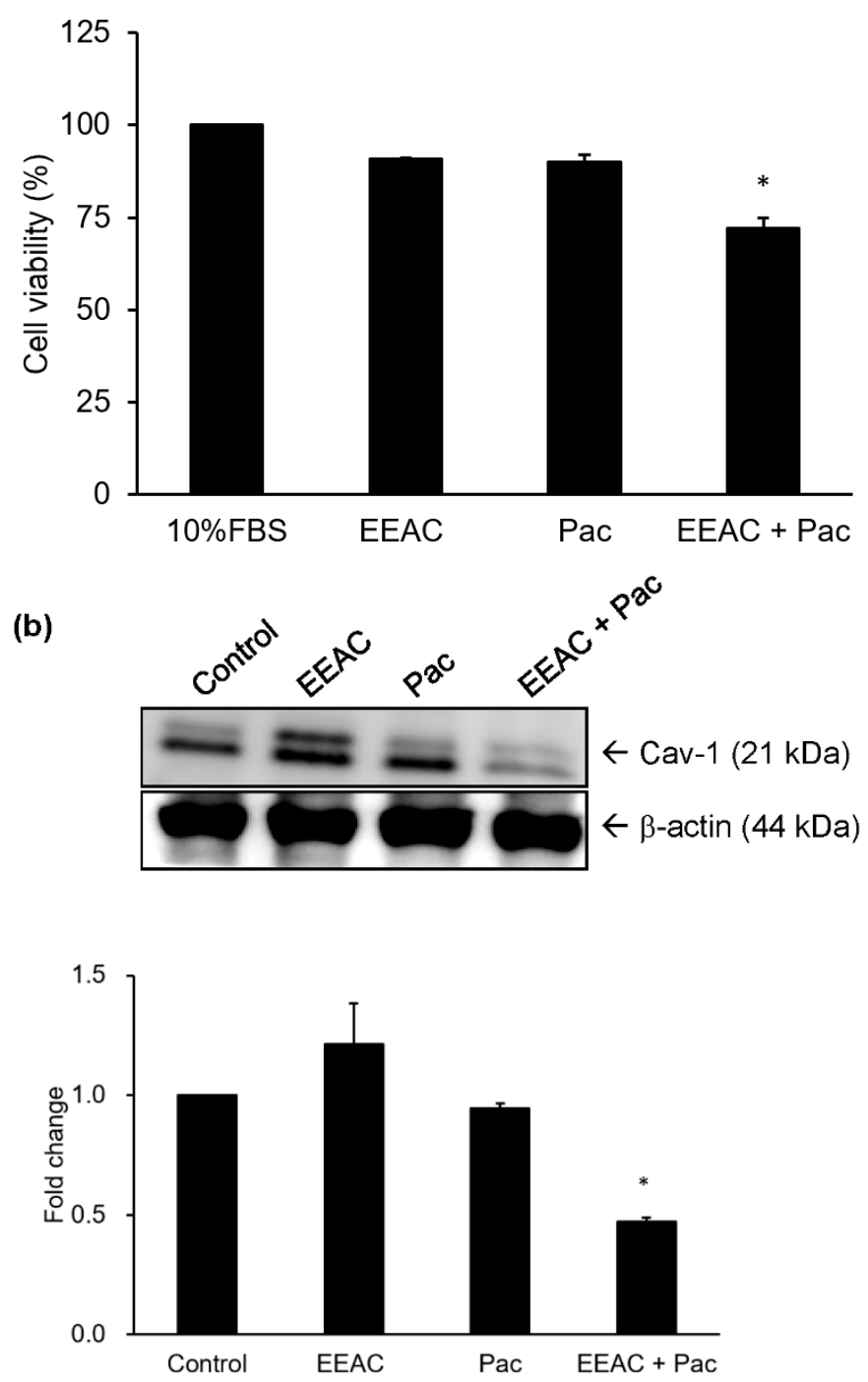

Figure 6. EEAC enhanced chemosensitivity of A549 cell to paclitaxel. Cells were incubated with EEAC $(6.25 \mu \mathrm{g} / \mathrm{mL})$, paclitaxel $(0.156 \mu \mathrm{M}$; Pac) or EEAC combined with paclitaxel for $24 \mathrm{~h}$ to examine the change of cell viability (a). Under the same experimental condition, the expression level of cav-1 protein was examined using Western blot $(\mathbf{b})$. The band intensities of each group were quantified and normalized to the control group, and the relative expression of cav-1 protein was presented as fold change in a histogram. ${ }^{*}$ indicates $p<0.05$ as compared with paclitaxel alone group. Pac, paclitaxel; Cav-1, caveolin-1. 


\subsection{Effect of EEAC on the Expressions of Cyclin D1 and MMP-9 in LLC Cells}

To investigate whether EEAC affects regulators involved in the cell cycle and migration in LLC cells, cells were treated with EEAC $(25 \mu \mathrm{g} / \mathrm{mL})$ for $24 \mathrm{~h}$. Experimental result indicated that the protein levels of MMP-9 and cyclin D1 were markedly reduced to $33 \%$ and $26 \%$, respectively, after EEAC treatment (Figure 7).
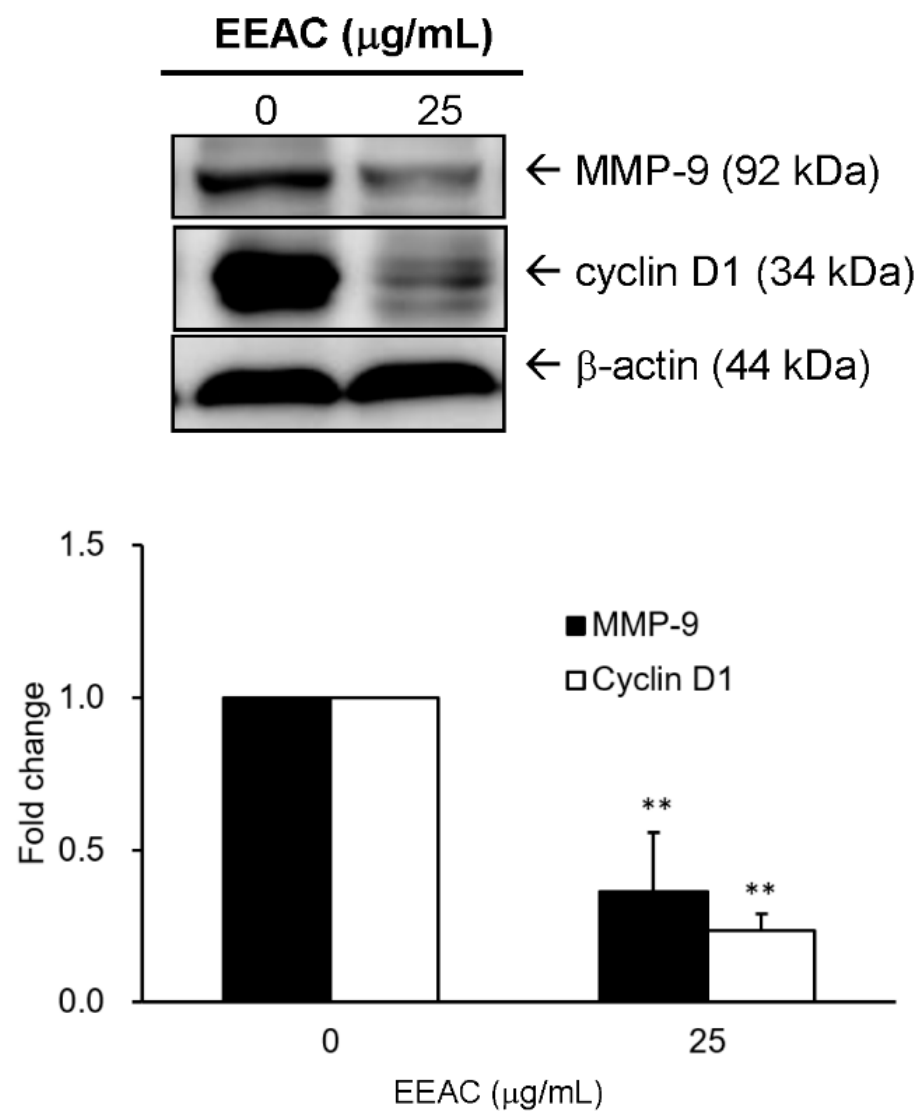

Figure 7. Effect of EEAC on cyclin D1 and MMP-9 expressions in LLC cells. Cells were incubated with $25 \mu \mathrm{g} / \mathrm{mL}$ EEAC for $24 \mathrm{~h}$ to analyze translational levels of cyclin D1 and MMP-9 proteins. The band intensities of each group were quantified and normalized to the control group (treated with vehicle alone), and the relative expressions of detected proteins were presented as fold change in a histogram.

** indicates $p<0.01$ as compared with control group, respectively.

\subsection{EEAC Reduced Tumor Growth in the Lewis Lung Carcinoma Allograft Mode}

The results showed that a seven-day treatment of EEAC $(0.25$ and $0.5 \mathrm{~g} / \mathrm{kg})$ markedly reduced tumor size by $30 \%$ and $58 \%$, respectively, as compared to the PC group (treated with vehicle alone; Figure $8 \mathrm{a}, \mathrm{b})$. These results also showed that a 14-day treatment of EEAC $(0.25$ and $0.5 \mathrm{~g} / \mathrm{kg})$ obviously reduced tumor size by $68 \%$ and $76 \%$, respectively, as compared to the PC group. However, the body weights between EEAC group and PC group did not show significantl differences after seven or 14 days of oral administration (Figure 8c). 
(a)

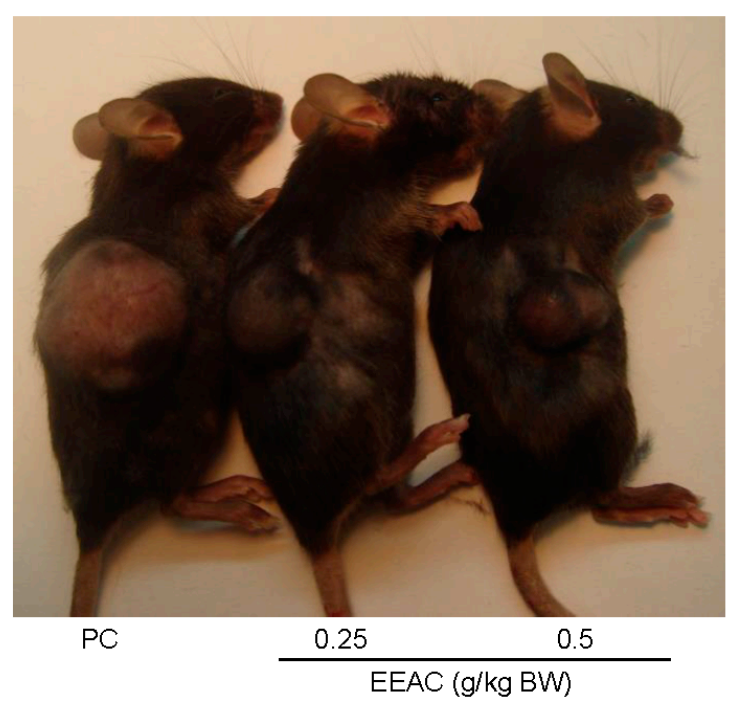

(b)

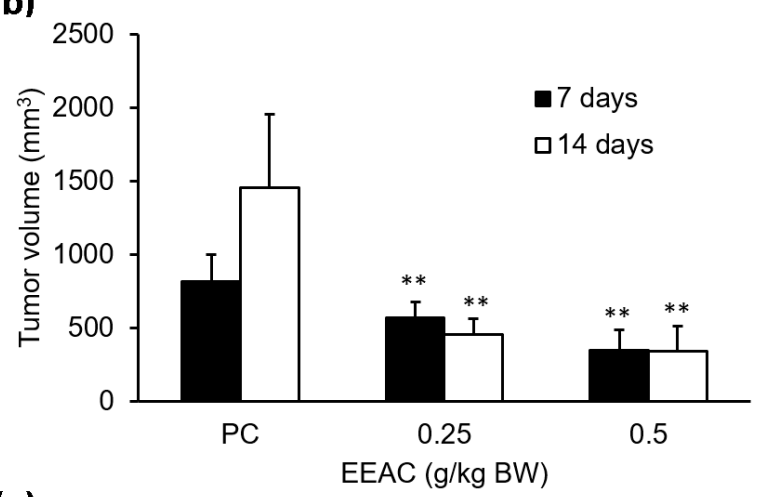

(c)

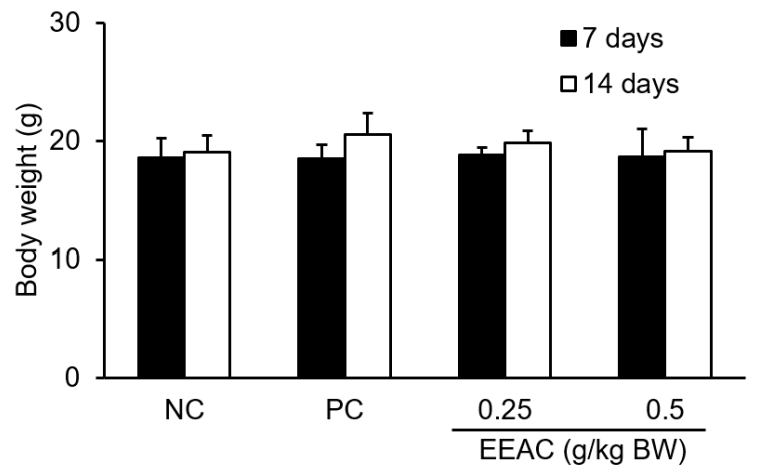

Figure 8. EEAC inhibited tumor growth in the Lewis lung carcinoma allograft model. The tumor tissue denoted by a dashed line was photographed at the end of the study. (a) Tumor volume (b) and bodyweight (c) of each group are shown as a histogram. NC: normal control, PC: LLC group. ${ }^{* *} p<0.01$ compared to the PC group (treated with vehicle alone).

\section{Discussion}

Several bioactive compounds from EEAC, such as antroquinonol, 4-acetylantroquinonol B and zhankuic acid A, have been reported to be effective in reducing cell proliferation of hepatoma, colon cancer and leukemia cells [14-16]. Our previous study has identified three compounds including, adenosine, cordycepin and zhankuic acid A from EEAC [13]. Of these compounds, the G2/M arrest of cordycepin, which regulated cyclin D1, cyclin B1 and p21 protein, has been investigated in melanoma, bladder and colon cancer cells [17-21]. Besides, Chen et al. reported that zhankuic acid A exhibited 
cytotoxic activity against P-388 murine leukemia cells [22]. These may be due to regulation of CDKs and CDKIs and subsequent blocking of cell cycle progression [23,24]. In addition, studies have reported that cyclin D1, cyclin E, MMP-2 and MMP-9 are associated with tumor growth and metastasis inhibition in an A549 cell and its xenograft mouse tumor model [25-27].

In our previous study, cordycepin $(0.16 \mathrm{mg} / \mathrm{g})$ and zhankuic acid A $(235 \mathrm{mg} / \mathrm{g})$ were found in EEAC, respectively [13]. Thus, in accordance with concentrations found in the former, the $100 \mu \mathrm{g} / \mathrm{mL}$ EEAC solution were used to investigate their effect on cyclin D1 protein expression in the present study. After treatment with cordycepin and zhankuic acid A, cyclin D1 protein levels were markedly decreased in A549 cells (Figure 5). This may partially explain how these two major constituents of EEAC are involved in the regulation of A549 cell cycle arrest, which correlated with the decreasing cell viability and inducing G0/G1 and S phases arrest (Figure 1).

Both of p21 and p27 are known to regulate G1/S and G2/M transitions [28]. Niculescu et al. also provided evidence that $\mathrm{p} 21$ can regulate the phosphorylation of $\mathrm{Rb}$ and the subsequent blocking of DNA replication to prevent endoreduplication in different cancer cells at both the G1/S and the G2/M cell cycle transitions [29]. Moreover, p27-deficiency enhances chronic hepatocyte injury-induced liver tumorigenesis by overexpression of cyclin E1, which contributes to the activation of cdk2 [30]. Our results demonstrated that the protein levels of p21 and p27were increased, and the levels of cyclin D1 and cyclin E were decreased in A549 cells after treatment with EEAC (Figure 2b).

Many studies indicated AMPK dysfunction increases the viability of lung cancer [31]. Our results indicated that EEAC not only increased the activation of AMPK $\alpha$ but also decreased Akt and mTOR expression in A549 cells (Figure 2a and Table 1). This may be attributed to the regulations of zhankuic acid A and cordycepin in AMPK and Akt [32,33]. Several studies showed that Akt and ERK1/2 signaling pathways modulate cell migration and invasion by regulating MMP expression in NSCLC $[34,35]$. Besides, more than $34 \%$ of lung tumor tissues of NSCLC patients were observed to have higher levels of activated ERK1/2 as compared with normal tissue sections [36], indicating advanced and aggressive NSCLC tumors. A study also revealed that inactivation of ERK $1 / 2$ was found to inhibit the migration and invasion of lung cancer cells [37]. In our study, the decrease of reported cell migration can be observed after administrating EEAC (Figure 3). The results showed that the phosphorylations ofAkt and ERK1/2 as well as the protein expressions of MMP-2 and 9 were significantly decreased which is similar to what was reported in previous studies (Figures 2a and 4).

Chemotherapy remains a standard remedy for advanced cancer. Pac, a valuable cancer chemotherapeutic agent, is widely applied in the treatment of many metastatic types of cancer, including ovary, breast, and lung carcinomas. However, cancer cells may also be resistant to Pac, which causes failure during treatments and increased mortality, and this turns out to be a major clinical concern. Cav- 1 is a membrane-associated protein with two isoforms, caveolin- $1 \alpha$ and $\beta$, that is not only a putative regulator of cellular transformation but also a regulator of the activity of survival-associated proteins, such as Src kinases, epidermal growth factor tyrosine kinase, Her2/neu (ErbB2) kinase, ERK, endothelial nitric-oxide synthase, and $\mathrm{G}$ proteins [38]. Cav-1 also inhibits serine/threonine protein phosphatases (PP1 and PP2A). This inhibition leads to an up-regulation of Akt and ERK1/2 activation and subsequently induces cancer cell growth [39]. Moreover, silencing of the cav-1 gene enhanced doxorubicin-induced apoptosis and reduced lung metastasis in human renal cell carcinoma [40]. Our results suggest that using non-toxic Pac combined with EEAC reduced the protein expression of cav-1 compared to applying Pac alone (Figure 6a,b). Pac co-treatment with EEAC exhibited enhanced chemosensitivity of A549 cells. These results indicate that EEAC could be an adjuvant remedy to alleviate the clinical problem of paclitaxel resistance in NSCLC.

According to the present study, A549 and LLC cells showed regulation of protein levels related to cell cycle and migration in response to EEAC treatment (Figures 1, 2, 4, and 7). Therefore, we used an C57BL/6J mice allograft tumor model to evaluate the anticancer effect of EEAC and the results showed that EEAC significantly decreased the average tumor volume of C57BL/6J mice injected with Lewis lung cancer cells without affecting mice body weight (Figure 8). 
In conclusion, our investigation demonstrated that EEAC has effective inhibitory activities on cell growth, migration and paclitaxel resistance ofA549 cancer cells. These pharmacological effects might be partially mediated through inhibiting gelatinases to reduce migratory ability as well as by suppressing the growth-promoting proteins, Akt, ERK1/2, cyclin D1, and cyclin E, and by the activating growth-suppressing proteins, p-AMPK, p21 and p27, to decrease cell growth. EEAC also decreased the protein expression of cav-1 to enhance the cytotoxicity of paclitaxel in A549 cells. The result obtained from the murine allograft tumor model indicated that EEAC has anti-tumor activity. Therefore, EEAC has potential for development as an adjuvant drug for clinical chemotherapy of lung cancer.

\section{Materials and Methods}

\subsection{Materials}

Fetal bovine serum (FBS), penicillin G, Dulbecco's modified Eagle's medium (DMEM), Ham's F12K medium, and streptomycin were obtained from Invitrogen (Carlsbad, CA, USA). Sodium pyruvate and non-essential amino acids were purchased from Biological Industries (Kibbutz Beit Haemek, Israel). Primary antibodies against p-Rb (\#sc-16670), p-ERK1/2 (\#sc-7383) and ERK1/2 (\#sc-154) were purchased from Santa Cruz Biotechnology (Santa Cruz, CA, USA). Antibodies recognized p-AMPK (\#2535), caveolin-1 (\#3238), p-mTOR (\#2971) and AMPK $\alpha$ (\#2793) were obtained from Cell signaling Technology (Beverly, MA, USA). Antibodies against Akt (ab28422), p-Akt (\#ab28821), MMP-2 (\#ab37150), MMP-9 (\#ab58803), p21 (\#ab379601) and $\beta$-actin (\#ab8226) were from Abcam (Cambridge, MA, USA).Anti-p27 (\#GTX100446), Anti-cyclin D1 (\#GTX27958), and Anti-cyclin E (\#GTX27959) antibodies were obtained from GeneTex (Irvine, CA, USA). Secondary antibodies conjugated with horseradish peroxidase (HRP) were obtained from Santa Cruz Biotechnology. The zhankuic acid A was isolated, purified and identified according to our previous study [41]. Other reagents were purchased from Sigma-Aldrich (St. Louis, MO, USA).

\subsection{Preparation of Ethanolic Extract of Antrodia cinnamomea (EEAC)}

The extraction procedure of EEAC was performed according to our previous study [42]. A stock solution EEAC was prepared as $100 \mathrm{mg} / \mathrm{mL}$ by $95 \%$ ethanol for in vitro studies. For in the vivo study, EEAC was firstly dissolved in $95 \%$ ethanol to give a $650 \mathrm{mg} / \mathrm{mL}$ stock solution that was further diluted to $65 \mathrm{mg} / \mathrm{mL}$ by PBS solution with $0.5 \%(v / v)$ Tween- 80 .

\subsection{Cell Culture}

A549 cells (\#BCRC-60074), a human lung adenocarcinoma cell line, and LLC cells (\#BCRC-60050), a mouse Lewis lung carcinoma, were obtained from the Bioresource Collection and Research Center (BCRC) of the Food Industry Research and Development Institute (Hsinchu, Taiwan). A549 cells were cultured in Ham's F12K medium supplemented with 10\% fetal bovine serum (FBS; \#10099-141, Invitrogen), $1.5 \mathrm{~g} / \mathrm{L}$ sodium bicarbonate, $2 \mathrm{mM}$ L-glutamine, 100 units $/ \mathrm{mL}$ penicillin $\mathrm{G}$ and $100 \mu \mathrm{g} / \mathrm{mL}$ streptomycin sulfate. LLC cells were maintained in DMEM medium containing 10\% FBS, $1.5 \mathrm{~g} / \mathrm{L}$ sodium bicarbonate, $4 \mathrm{mM}$ L-glutamine, $4.5 \mathrm{~g} / \mathrm{L}$ glucose, 100 units $/ \mathrm{mL}$ penicillin $\mathrm{G}$ and $100 \mu \mathrm{g} / \mathrm{mL}$ streptomycin sulfate. All cells were incubated in a humidifier with $5 \% \mathrm{CO}_{2}$ at $37^{\circ} \mathrm{C}$, and the culture medium was refreshed every 2 days.

\subsection{Cell Viability Assay (MTT Assay)}

A549 cells $\left(2 \times 10^{4}\right.$ cells / well) were seeded into a 96-well overnight. A549 cells were exposed to $100 \mu \mathrm{L}$ of different concentrations of the tested drugs (e.g., EEAC or paclitaxel) in culture medium. After $24 \mathrm{~h}$ of treatment, $10 \mu \mathrm{L}$ of $5 \mathrm{mg} / \mathrm{mL}$ MTT (3-(4,5-dimethylthiazol-2-yl)-2,5-diphenyl tetrazolium bromide) was added into each well. After $4 \mathrm{~h}$ incubation, cells were washed twice with $1 \times$ PBS, and then $200 \mu \mathrm{L}$ of dimethyl sulfoxide (DMSO) was added to each well. Absorbance values at $570 \mathrm{~nm}$ 
were determined for each well using $650 \mathrm{~nm}$ as the reference wavelength. The absorbance can be correlated to the percentage of vital cells by comparison with the control group (without treatment of tested drugs). The cell viability ratio was calculated by the following formula: cell viability $(\%)=\mathrm{OD}$ (treated)/OD (control) $\times 100 \%$.

\subsection{Cell Cycle Analysis}

EEAC-treated cells were harvested, washed twice with cold $1 \times$ PBS, and then fixed with chilled $70 \%$ ethanol overnight. After ethanol was removed by centrifugation at $1500 \mathrm{rpm}$ for $15 \mathrm{~min}$ at $4{ }^{\circ} \mathrm{C}$, the cell pellets were re-suspended in $500 \mu \mathrm{L}$ of DNA staining buffer containing $4 \mu \mathrm{g} / \mathrm{mL}$ of propidium iodide, $1 \%$ Triton X-100 and $0.1 \mathrm{mg} / \mathrm{mL}$ RNase A and incubated for $30 \mathrm{~min}$ at room temperature in the dark. The cell cycle profile was analyzed using FACSCanto system (BD Biosciences, San Jose, CA, USA). Post-acquisition data analysis was performed using ModFit LT software (Verify Software House, Topsham, ME, USA).

\subsection{Wound-Healing Analysis}

Cells $\left(2.5 \times 10^{4}\right.$ cells/well) were seeded into 24 -well plates overnight. After $24 \mathrm{~h}$ of starvation, a cell-free gap was created with a $200 \mu \mathrm{L}$ micropipette tip and then the cells were treated with various concentrations of EEAC in normal culture medium. Photographs of the cell-free gap were taken at 0,12 and $24 \mathrm{~h}$ after treatment, and the area of the cell-free gap was measured by Image J software (NIH, Bethesda, MD, USA). Migration inhibition was presented as the percentage of wound closure by calculating the cell-free gap of each group compared to those at the initial time $(0 \mathrm{~h})$.

\subsection{Western Blot Analysis}

Harvested cells were lysed by PRO-PREP Protein Extraction Kit (iNtRON Biotechnology, Gyeonggi-do, Korea) 5and centrifuged at $10,000 \mathrm{rpm}$ at $4{ }^{\circ} \mathrm{C}$ for $30 \mathrm{~min}$. The supernatant was incubated at $95^{\circ} \mathrm{C}$ for $5 \mathrm{~min}$ in $6 \times$ sample loading buffer containing $0.35 \mathrm{M}$ Tris- $\mathrm{HCl}(\mathrm{pH} 6.8), 10 \%$ SDS, $30 \%$ glycerol, $0.12 \%$ bromophenol blue and $6 \% \beta$-mercaptoethanol. About $50 \mu \mathrm{g}$ of total protein was separated by $10 \%$ sodium dodecyl sulfate-polyacrylamide gel electrophoresis (SDS-PAGE) followed by blotting to a polyvinylidene fluoride (PVDF) membrane (NEF1002001PK; Perkin Elmer, Boston, MA, USA). Non-specific binding of the blotted membrane was blocked by using $5 \%$ non-fat milk dissolved in $1 \times$ Tris-buffered saline (TBS) with $0.2 \%$ Tween 20 (0.2\% TBST). The membrane was incubated with the primary antibody (in $0.2 \%$ TBST) overnight at $4{ }^{\circ} \mathrm{C}$. Subsequently, the secondary antibody (in $0.2 \%$ TBST) was applied for $3 \mathrm{~h}$ at $4{ }^{\circ} \mathrm{C}$. The expected protein bands were visualized using the ECL reaction (Amersham, Arlington Height, IL, USA), and the luminescence signal was acquired with the Fujifilm LAS-4000 system (San Leandro, CA, USA). Band intensity was analyzed using MultiGauge software (Fujifilm). The band intensity of individual proteins was normalized to that of $\beta$-actin and presented as the fold change from the control group (without the treatment of tested drugs).

\subsection{Lewis Lung Cancer Allograft Model in C57BL/6J Mice}

Male C57BL/6J mice (6 weeks old) were obtained from BioLASCO (Taipei, Taiwan). The C57BL/6J mice were housed in the Laboratory Animal Center, China Medical University (Taichung, Taiwan) and kept on $12 \mathrm{~h} \mathrm{light} /$ dark cycles at $25^{\circ} \mathrm{C}$. The animal experiments were approved by the Institutional Animal Care and Use Committee of China Medical University (IACUC; approval ID: 102-194-C, approval date: 04-01-2013). All animal care followed the institutional animal ethical guidelines of China Medical University. After adaptation for 1 week, C57BL/6J mice were randomly divided into subcutaneously implanted with LLC cells $\left(7 \times 10^{5}\right.$ cells in $100 \mu \mathrm{L}$ of cell culture medium). After $2 \sim 3$ weeks of tumor induction, mice were randomly divided into four groups ( $n=6 /$ group): Group I (normal control group, NC) was given vehicle solvent. Group II (untreated LLC group, PC) was grafted with LLC cells and given vehicle solvent. Group III was grafted with LLC cells and then treated with EEAC $(0.25 \mathrm{~g} / \mathrm{kg})$. Group IV was grafted with LLC cells and then treated with EEAC 
$(0.5 \mathrm{~g} / \mathrm{kg})$. The EEAC and vehicle solvent was administrated by oral gavage once a day for 2 weeks. Tumor width $(\mathrm{W})$ and length $(\mathrm{L})$ were measured by calipers every week to calculate the tumor volume by the formula: $\mathrm{L} \times \mathrm{W}^{2} \times 0.52$ [16]. Body weight was also recorded every week during the study.

\subsection{Statistical Analysis}

All data are presented as mean \pm standard deviation (S.D.). All experiments were done in triplicate. Statistical significance was evaluated by one-way ANOVA with a Bonferroni post-hoc test. A value of $p<0.05$ was regarded as being statistically significant.

Acknowledgments: This study was supported from China Medical University (CMU93-BST-01, CMU97-084, and CMU105-ASIA-19). We especially thank Yu-Hsuan Lin, Tai-Yun Wu, and Pei-Hua Tu for their helps in the animal experiments.

Author Contributions: Chi-Han Wu, Fon-Chang Liu, Chieh-His Wu and Ming-Jyh Sheu conceived and designed the experiments; Chi-Han $\mathrm{Wu}$, Chun-Hsu Pan and Fon-Chang Liu performed the experiments; Chi-Han $\mathrm{Wu}$, Chun-Hsu Pan and Fon-Chang Liu analyzed the data; Ming-Tsung Lai and Shou-Jen Lan contributed materials; Chi-Han Wu, Chun-Hsu Pan and Ming-Jyh Sheu wrote the paper.

Conflicts of Interest: The authors declare no conflict of interest.

\section{References}

1. Ho, M.M.; Ng, A.V.; Lam, S.; Hung, J.Y. Side population in human lung cancer cell lines and tumors is enriched with stem-like cancer cells. Cancer Res. 2007, 67, 4827-4833. [CrossRef] [PubMed]

2. Chellappan, S.P.; Giordano, A.; Fisher, P.B. Role of cyclin-dependent kinases and their inhibitors in cellular differentiation and development. Curr. Top. Microbiol. Immunol. 1998, 227, 57-103. [PubMed]

3. Sherr, C.J. G1 phase progression: Cycling on cue. Cell 1994, 79, 551-555. [CrossRef]

4. Motoshima, H.; Goldstein, B.J.; Igata, M.; Araki, E. AMPK and cell proliferation-AMPK as a therapeutic target for atherosclerosis and cancer. J. Physiol. 2006, 574, 63-71. [CrossRef] [PubMed]

5. LoPiccolo, J.; Granville, C.A.; Gills, J.J.; Dennis, P.A. Targeting Akt in cancer therapy. Anticancer Drugs 2007, 18, 861-874. [PubMed]

6. Yoon, S.O.; Park, S.J.; Yun, C.H.; Chung, A.S. Roles of matrix metalloproteinases in tumor metastasis and angiogenesis. J. Biochem. Mol. Biol. 2003, 36, 128-137. [CrossRef] [PubMed]

7. Roomi, M.W.; Monterrey, J.C.; Kalinovsky, T.; Rath, M.; Niedzwiecki, A. Patterns of MMP-2 and MMP-9 expression in human cancer cell lines. Oncol. Rep. 2009, 21, 1323-1333. [PubMed]

8. Ho, C.C.; Kuo, S.H.; Huang, P.H.; Huang, H.Y.; Yang, C.H.; Yang, P.C. Caveolin-1 expression is significantly associated with drug resistance and poor prognosis in advanced non-small cell lung cancer patients treated with gemcitabine-based chemotherapy. Lung Cancer 2008, 59, 105-110. [CrossRef] [PubMed]

9. Park, J.; Bae, E.; Lee, C.; Yoon, S.S.; Chae, Y.S.; Ahn, K.S.; Won, N.H. RNA interference-directed caveolin-1 knockdown sensitizes SN12CPM6 cells to doxorubicin-induced apoptosis and reduces lung metastasis. Tumour Biol. 2010, 31, 643-650. [CrossRef] [PubMed]

10. Chu, Y.C.; Yang, R.M.; Chang, T.T.; Chou, J.C. Fructification of Antrodia cinnamomea was strain dependent in malt extract media and involved specific gene expression. J. Agric. Food Chem. 2010, 58, 257-261. [CrossRef] [PubMed]

11. Shang, K.M.; Su, T.H.; Lee, W.L.; Hsiao, W.W.; Chiou, C.Y.; Ho, B.Y.; Wang, S.Y.; Shyur, L.F. Novel effect and the mechanistic insights of fruiting body extract of medicinal fungus Antrodia cinnamomea against T47D breast cancer. Phytomedicine 2017, 24, 39-48. [CrossRef] [PubMed]

12. Tsai, M.Y.; Hung, Y.C.; Chen, Y.H.; Chen, Y.H.; Huang, Y.C.; Kao, C.W.; Su, Y.L.; Chiu, H.H.; Rau, K.M. A preliminary randomised controlled study of short-term Antrodia cinnamomea treatment combined with chemotherapy for patients with advanced cancer. BMC Complement. Altern. Med. 2016, 16. [CrossRef] [PubMed]

13. Chen, Y.Y.; Chou, P.Y.; Chien, Y.C.; Wu, C.H.; Wu, T.S.; Sheu, M.J. Ethanol extracts of fruiting bodies of Antrodia cinnamomea exhibit anti-migration action in human adenocarcinoma CL1-0 cells through the MAPK and PI3K/AKT signaling pathways. Phytomedicine 2012, 19, 768-778. [CrossRef] [PubMed] 
14. Yeh, C.T.; Rao, Y.K.; Yao, C.J.; Yeh, C.F.; Li, C.H.; Chuang, S.E.; Luong, J.H.; Lai, G.M.; Tzeng, Y.M. Cytotoxic triterpenes from Antrodia camphorata and their mode of action in HT-29 human colon cancer cells. Cancer Lett. 2009, 285, 73-79. [CrossRef] [PubMed]

15. Chiang, P.C.; Lin, S.C.; Pan, S.L.; Kuo, C.H.; Tsai, I.L.; Kuo, M.T.; Wen, W.C.; Chen, P.; Guh, J.H. Antroquinonol displays anticancer potential against human hepatocellular carcinoma cells: A crucial role of AMPK and mTOR pathways. Biochem. Pharmacol. 2010, 79, 162-171. [CrossRef] [PubMed]

16. Lin, Y.W.; Pan, J.H.; Liu, R.H.; Kuo, Y.H.; Sheen, L.Y.; Chiang, B.H. The 4-acetylantroquinonol B isolated from mycelium of Antrodia cinnamomea inhibits proliferation of hepatoma cells. J. Sci. Food Agric. 2010, 90, 1739-1744. [CrossRef] [PubMed]

17. Yoshikawa, N.; Yamada, S.; Takeuchi, C.; Kagota, S.; Shinozuka, K.; Kunitomo, M.; Nakamura, K. Cordycepin ( $3^{\prime}$-deoxyadenosine) inhibits the growth of B16-BL6 mouse melanoma cells through the stimulation of adenosine A3 receptor followed by glycogen synthase kinase-3 $\beta$ activation and cyclin D1 suppression. Naunyn Schmiedebergs Arch. Pharmacol. 2008, 377, 591-595. [CrossRef] [PubMed]

18. Ernens, I.; Rouy, D.; Velot, E.; Devaux, Y.; Wagner, D.R. Adenosine inhibits matrix metalloproteinase-9 secretion by neutrophils: Implication of A2a receptor and cAMP/PKA/Ca ${ }^{2+}$ pathway. Circ. Res. 2006, 99, 590-597. [CrossRef] [PubMed]

19. Wu, W.C.; Hsiao, J.R.; Lian, Y.Y.; Lin, C.Y.; Huang, B.M. The apoptotic effect of cordycepin on human OEC-M1 oral cancer cell line. Cancer Chemother. Pharmacol. 2007, 60, 103-111. [CrossRef] [PubMed]

20. Lee, S.J.; Kim, S.K.; Choi, W.S.; Kim, W.J.; Moon, S.K. Cordycepin causes p21WAF1-mediated G2/M cell-cycle arrest by regulating c-Jun N-terminal kinase activation in human bladder cancer cells. Arch. Biochem. Biophys. 2009, 490, 103-109. [CrossRef] [PubMed]

21. Lee, S.J.; Moon, G.S.; Jung, K.H.; Kim, W.J.; Moon, S.K. c-Jun N-terminal kinase 1 is required for cordycepin-mediated induction of G2/M cell-cycle arrest via p21WAF1 expression in human colon cancer cells. Food Chem. Toxicol. 2010, 48, 277-283. [CrossRef] [PubMed]

22. Chen, C.H.; Yang, S.W.; Shen, Y.C. New steroid acids from Antrodia cinnamomea, a fungal parasite of Cinnamomum micranthum. J. Nat. Prod. 1995, 58, 1655-1661. [CrossRef] [PubMed]

23. Song, P.; Wang, S.; He, C.; Wang, S.; Liang, B.; Viollet, B.; Zou, M.H. AMPK $\alpha 2$ deletion exacerbates neointima formation by upregulating Skp2 in vascular smooth muscle cells. Circ. Res. 2011, 109, 1230-1239. [CrossRef] [PubMed]

24. Hseu, Y.C.; Chen, S.C.; Chen, H.C.; Liao, J.W.; Yang, H.L. Antrodia camphorata inhibits proliferation of human breast cancer cells in vitro and in vivo. Food Chem. Toxicol. 2008, 46, 2680-2688. [CrossRef] [PubMed]

25. Huang, H.; Hu, Y.D.; Li, N.; Zhu, Y. Inhibition of tumor growth and metastasis by non-small cell lung cancer cells transfected with cyclin D1-targeted siRNA. Oligonucleotides 2009, 19, 151-162. [CrossRef] [PubMed]

26. Jiang, G.; Wang, Y.; Dai, S.; Liu, Y.; Stoecker, M.; Wang, E.; Wang, E. P120-catenin isoforms 1 and 3 regulate proliferation and cell cycle of lung cancer cells via $\beta$-catenin and Kaiso respectively. PLoS ONE 2012, 7. [CrossRef] [PubMed]

27. Lien, S.; Lowman, H. Therapeutic anti-VEGF antibodies. In Therapeutic Antibodies; Springer: Berlin/Heidelberg, Germany, 2008.

28. Deep, G.; Singh, R.P.; Agarwal, C.; Kroll, D.J.; Agarwal, R. Silymarin and silibinin cause G1 and G2-M cell cycle arrest via distinct circuitries in human prostate cancer PC3 cells: A comparison of flavanone silibinin with flavanolignan mixture silymarin. Oncogene 2006, 25, 1053-1069. [CrossRef] [PubMed]

29. Niculescu, A.B., 3rd; Chen, X.; Smeets, M.; Hengst, L.; Prives, C.; Reed, S.I. Effects of p21(Cip1/Waf1) at both the G1/S and the G2/M cell cycle transitions: $\mathrm{pRb}$ is a critical determinant in blocking DNA replication and in preventing endoreduplication. Mol. Cell. Biol. 1998, 18, 629-643. [CrossRef] [PubMed]

30. Sun, D.; Ren, H.; Oertel, M.; Sellers, R.S.; Zhu, L. Loss of p27Kip1 enhances tumor progression in chronic hepatocyte injury-induced liver tumorigenesis with widely ranging effects on Cdk2 or Cdc2 activation. Carcinogenesis 2007, 28, 1859-1866. [CrossRef] [PubMed]

31. Carretero, J.; Medina, P.P.; Blanco, R.; Smit, L.; Tang, M.; Roncador, G.; Maestre, L.; Conde, E.; Lopez-Rios, F.; Clevers, H.C.; et al. Dysfunctional AMPK activity, signalling through mTOR and survival in response to energetic stress in LKB1-deficient lung cancer. Oncogene 2007, 26, 1616-1625. [CrossRef] [PubMed]

32. Yu, C.C.; Chiang, P.C.; Lu, P.H.; Kuo, M.T.; Wen, W.C.; Chen, P.; Guh, J.H. Antroquinonol, a natural ubiquinone derivative, induces a cross talk between apoptosis, autophagy and senescence in human pancreatic carcinoma cells. J. Nutr. Biochem. 2012, 23, 900-907. [CrossRef] [PubMed] 
33. Wong, Y.Y.; Moon, A.; Duffin, R.; Barthet-Barateig, A.; Meijer, H.A.; Clemens, M.J.; de Moor, C.H. Cordycepin inhibits protein synthesis and cell adhesion through effects on signal transduction. J. Biol. Chem. 2010, 285, 2610-2621. [CrossRef] [PubMed]

34. Chang, Y.M.; Shih, Y.T.; Chen, Y.S.; Liu, C.L.; Fang, W.K.; Tsai, C.H.; Tsai, F.J.; Kuo, W.W.; Lai, T.Y.; Huang, C.Y. Schwann cell migration induced by earthworm extract via activation of PAs and MMP2/9 mediated through ERK1/2 and p38. Evid.-Based Complement. Altern. Med. 2011, 2011. [CrossRef] [PubMed]

35. Lee, I.T.; Lin, C.C.; Wu, Y.C.; Yang, C.M. TNF- $\alpha$ induces matrix metalloproteinase-9 expression in A549 cells: Role of TNFR1/TRAF2/PKC $\alpha$-dependent signaling pathways. J. Cell. Physiol. 2010, 224, 454-464. [CrossRef] [PubMed]

36. Vicent, S.; Lopez-Picazo, J.M.; Toledo, G.; Lozano, M.D.; Torre, W.; Garcia-Corchon, C.; Quero, C.; Soria, J.C.; Martin-Algarra, S.; Manzano, R.G.; et al. ERK1/2 is activated in non-small-cell lung cancer and associated with advanced tumours. Br. J. Cancer 2004, 90, 1047-1052. [CrossRef] [PubMed]

37. Liao, Y.C.; Shih, Y.W.; Chao, C.H.; Lee, X.Y.; Chiang, T.A. Involvement of the ERK signaling pathway in fisetin reduces invasion and migration in the human lung cancer cell line A549. J. Agric. Food Chem. 2009, 57, 8933-8941. [CrossRef] [PubMed]

38. Shajahan, A.N.; Wang, A.; Decker, M.; Minshall, R.D.; Liu, M.C.; Clarke, R. Caveolin-1 tyrosine phosphorylation enhances paclitaxel-mediated cytotoxicity. J. Biol. Chem. 2007, 282, 5934-5943. [CrossRef] [PubMed]

39. Li, L.; Ren, C.H.; Tahir, S.A.; Ren, C.; Thompson, T.C. Caveolin-1 maintains activated Akt in prostate cancer cells through scaffolding domain binding site interactions with and inhibition of serine/threonine protein phosphatases PP1 and PP2A. Mol. Cell. Biol. 2003, 23, 9389-9404. [CrossRef] [PubMed]

40. Tirado, O.M.; MacCarthy, C.M.; Fatima, N.; Villar, J.; Mateo-Lozano, S.; Notario, V. Caveolin-1 promotes resistance to chemotherapy-induced apoptosis in Ewing's sarcoma cells by modulating PKC $\alpha$ phosphorylation. Int. J. Cancer 2010, 126, 426-436. [CrossRef] [PubMed]

41. Shi, L.S.; Chao, C.H.; Shen, D.Y.; Chan, H.H.; Chen, C.H.; Liao, Y.R.; Wu, S.J.; Leu, Y.L.; Shen, Y.C.; Kuo, Y.H.; et al. Biologically active constituents from the fruiting body of Taiwanofungus camphoratus. Bioorg. Med. Chem. 2011, 19, 677-683. [CrossRef] [PubMed]

42. Liu, F.C.; Lai, M.T.; Chen, Y.Y.; Lin, W.H.; Chang, S.J.; Sheu, M.J.; Wu, C.H. Elucidating the inhibitory mechanisms of the ethanolic extract of the fruiting body of the mushroom Antrodia cinnamomea on the proliferation and migration of murine leukemia WEHI-3 cells and their tumorigenicity in a BALB/c allograft tumor model. Phytomedicine 2013, 20, 874-882. [CrossRef] [PubMed] 